\title{
The Confusion Continues: The New Dynamic of the Economic Loss Doctrine in Kansas*
}

\section{INTRODUCTION}

The economic loss doctrine has been labeled "obscure," "confusing," and "concerning." In its most basic form, the economic loss doctrine bars plaintiffs from making tort claims based on only economic losses. ${ }^{2}$ The doctrine is most typically applied to product liability claims. ${ }^{3}$ When the doctrine is applied, plaintiffs can recover for economic losses - as opposed to personal injury or property damage - only if they win on some other claim, such as breach of warranty. ${ }^{4}$ Although a precise definition of economic loss is difficult to ascertain and varies by jurisdiction, it encompasses "loss of the bargain, repair and replacement cost, loss of profits, and/or goodwill, including diminution in value." The economic loss

* Grant Treaster. J.D. Candidate 2015, University of Kansas School of Law; B.A., B.S. 2010, University of Kansas. I would like to thank the Kansas Law Review Board and Staff for their helpful insights and hard work. I would also like to thank Professors William Westerbeke and Stephen Ware for their invaluable guidance in helping to determine the boundary lines between warranty and tort law. I would also like to express my gratitude to my family and friends for their patience and encouragement. Finally, I would like to thank my wife, Brandy, for providing unwavering love, laughter and understanding throughout this process.

1. John J. Laubmeier, Comment, Demystifying Wisconsin's Economic Loss Doctrine, 2005 WIS. L. REV. 225, 225 (2005) (noting the description of economic loss as "an obscure legal doctrine"); Laura A. Wagner, Note, The Economic Loss Doctrine: A Recommendation for the Supreme Court of Pennsylvania, 72 U. PITT. L. REV. 825, 831 (2011) ("The state of the [economic loss doctrine] in Pennsylvania is highly confusing and allows for little to no predictability."); R. Thomas Cane \& Sheila Sullivan, More Litigation to Come: Exceptions to the Economic Loss Doctrine, Wis. LAw., Nov. 2005, at 10 (noting Wisconsin courts' concern with the doctrine).

2. Laubmeier, supra note 1 , at 225 ("The economic loss doctrine is a judicially created doctrine that bars recovery in tort for strictly economic losses arising from a contract.").

3. See, e.g., Hall v. Raley's, No. 3:08-CV-00632-RCJ-VPC, 2010 WL 55332, at *9 (D. Nev. Jan. 6, 2010) (citing Calloway v. City of Reno, 993 P.2d 1259, 1263-64 (Nev. 2000)) ("The economic loss doctrine was developed in product liability cases and states that there can be no recovery for purely economic losses in tort.").

4. Andrew Gray, Note, Drowning in A Sea of Confusion: Applying the Economic Loss Doctrine to Component Parts, Service Contracts, and Fraud, 84 WASH. U. L. REV. 1513, 1518 (2006) (citing Seely v. White Motor Co., 403 P.2d 145, 152 (Cal. 1965)) (explaining the view under the doctrine that "warranty law and contract remedies should govern the economic relations between the parties unless the product caused 'personal injury' or 'physical injury to the plaintiff's property"').

5. Kevin J. Breer \& Justin D. Pulikkan, The Economic Loss Rule in Kansas and Its Impact on 
doctrine was created judicially and has been adopted in various forms throughout the United States. ${ }^{6}$ The rationale for the doctrine began with the concern for unlimited liability because economic losses can result in wideranging liability based on one product. ${ }^{7}$ Courts also felt that the doctrine was needed to help separate warranty and tort claims, and to prevent warranty law from "drown[ing] in a sea of tort." 8 Recently, courts and commentators have recognized that the pendulum has swung and that expansion of the doctrine now threatens to drown tort law in a sea of warranty. ${ }^{9}$

In Kansas, the economic loss doctrine developed in the 1990s after the expansion of the doctrine in other jurisdictions. ${ }^{10}$ After the official adoption of the doctrine barred tort recovery for economic losses, Kansas courts began to expand the doctrine to contexts outside business products liability claims. ${ }^{11}$ However, after more than a decade of the doctrine's expansion in Kansas, the Kansas courts issued three cases that limit the reach of the doctrine. David v. Hett, Coker v. Siler, and Rinehart v. Morton Buildings, Inc. arose in the home construction context, and each case held that the economic loss doctrine did not bar the plaintiffs' tort claims. ${ }^{12}$

Construction Cases, J. Kan. B. Ass'N, June 2005, at 30, 30 (citing Nw. Ark. Mansonry, Inc. v. Summit Specialty Prods., Inc., 31 P.3d 982, 986-87 (Kan. Ct. App. 2001)).

6. Gray, supra note 4, at 1513 ("The doctrine was judicially developed to protect the right to allocate economic risks in contract."); see generally AMERICAN BAR ASS'N, STATE BY STATE SURVEY OF THE ECONOMIC LOSS DOCTRINE IN CONSTRUCTION LITIGATION (1996) (explaining the various approaches by states in applying the doctrine to construction cases).

7. See Hininger v. Case Corp., 23 F.3d 124, 128 (5th Cir. 1994) (quoting Nobility Homes of Tex., Inc. v. Shivers, 557 S.W.2d 77, 82 (Tex. 1977)) (recognizing that courts "fear that holding manufacturers liable for economic loss imposes unlimited and unforeseeable liability upon manufacturers").

8. E. River S.S. Corp. v. Transamerica Delaval, Inc., 476 U.S. 858, 866 (1986).

9. See, e.g., La Pesca Grande Charters, Inc. v. Moran, 704 So. 2d 710, 712 (Fla. Dist. Ct. App. 5th 1998) ("It is no more desirable to have tort law drown in a sea of contract than to have contract law drown in a sea of tort."). See also R. Joseph Barton, Note, Drowning in A Sea of Contract: Application of the Economic Loss Rule to Fraud and Negligent Misrepresentation Claims, 41 WM. \& MARY L. REV. 1789, 1791-92 (2000) ("Just as overextension of products liability would drown contract in a sea of tort, so too would over application of the economic loss rule drown misrepresentation claims in a sea of contract.").

10. Koss Const. v. Caterpillar, Inc., 960 P.2d 255, 259-60 (Kan. Ct. App. 1998) (discussing the economic loss doctrine and ultimately holding "that a commercial buyer of defective goods cannot sue in negligence or strict liability where the only injury consists of damage to the goods themselves" because "the economic loss doctrine applies to a claim for damage to the product itself").

11. See Jordan v. Case Corp., 993 P.2d 650, 652 (Kan. Ct. App. 1999) (applying the doctrine to consumer products liability claims); Nw. Ark. Masonry, Inc. v. Summit Specialty Prods., Inc., 31 P.3d 982, 989 (Kan. Ct. App. 2001) (applying the doctrine to a claim in the construction context for defective cement).

12. David v. Hett, 270 P.3d 1102 (Kan. 2011); Coker v. Siler, 304 P.3d 689 (Kan. Ct. App. 
The justifications for the economic loss doctrine do not exist in the home construction context, as the courts in David, Coker, and Rinehart properly recognized. However, each case raises questions about the scope of the doctrine in the home construction context and which economic loss claims a homeowner can bring in tort. These questions need to be addressed to ensure that the doctrine is applied correctly in the future.

This Comment analyzes the development of the economic loss doctrine in Kansas and the impact of these three recent cases. Although the cases seem logical in their limited holdings, they each create problems regarding the limitation of the doctrine outside the home construction context, the further blurring of the line between warranty and tort law, and the scope of tort liability for home construction defects. However, Kansas courts can begin to fix these problems by doing two things. First, Kansas courts should explicitly incorporate the independent duty rule into their economic loss doctrine analysis. Second, Kansas courts should consider several factorsthe gravity of harm of the defect, the bargaining positions of the parties, the nature of the claim's source as a service or a product, and whether the defect creates a non-economic risk of harm-to determine which home construction economic loss claims warrant recovery in tort.

Part II of this Comment explores the development of the economic loss doctrine in the United States and Kansas. First, it illustrates the development of the doctrine throughout the United States by explaining the doctrine's expansion and the ways in which courts have attempted to limit its scope through the creation of various exceptions. Part II also explores the development of the doctrine in Kansas courts, first with its adoption in the products liability context and then with its expansion into construction cases. Part III analyzes the three recent cases and discusses the ways in which the courts properly limited the doctrine. Part III also analyzes three specific problems that the recent Kansas cases created. Finally, this Comment explores the solutions Kansas courts can apply to begin to fix these problems. 


\section{BACKGROUND}

\section{A. Development of the Economic Loss Doctrine in the United States}

\section{The Introduction of Tort Law to Products Liability and the Response by the Economic Loss Doctrine}

The economic loss doctrine developed in the context of products liability law. ${ }^{13}$ In the early twentieth century, consumers injured by defective products could recover under negligence law and warranty law. However, both of these claims were often defeated by contractual warranty disclaimers or by the privity limitation, thereby creating harsh results for consumers. ${ }^{14}$ Traditional warranty law placed two major limitations on recovery by consumers of defective products. First, throughout the first half of the twentieth century, enforcement of warranty disclaimers prevented consumers from successfully asserting breach of warranty actions to recover damages caused by defective products. ${ }^{15}$ Product manufacturers and sellers could disclaim all liability, some liability, or limit the availability of certain remedies. ${ }^{16}$ Manufacturers and sellers of defective goods could thereby prevent liability if the manufacturer or seller successfully disclaimed liability. ${ }^{17}$ Second, courts required contractual privity between the consumer

13. Steven C. Tourek, Thomas H. Boyd, \& Charles J. Schoenwetter, Bucking the "Trend": The Uniform Commercial Code, The Economic Loss Doctrine, and Common Law Causes of Action for Fraud and Misrepresentation, 84 IowA L. REV. 875, 891 (1999) (“The Economic Loss Doctrine was developed to prevent product liability 'torts' from circumventing the objectives and terms of the U.C.C."); Hall v. Raley's, No. 3:08-CV-00632-RCJ-VPC, 2010 WL 55332, at *9 (D. Nev. Jan. 6, 2010) (citing Calloway v. City of Reno, 993 P.2d 1259, 1263-64 (Nev. 2000)) (explaining that "the economic loss doctrine was developed in product liability cases").

14. See Fleming James, Jr., Products Liability, 34 Tex. L. REv. 44, 44 (1955) (stating that the privity doctrine "was well adapted to protect the manufacturer from burdens on his activity, but it did so at the expense of the victims of his mistakes," and that products liability law developed in response "to ever-growing pressure for protection of the consumer, coupled with a realization that liability would not unduly inhibit the enterprise of manufacturers").

15. See William L. Prosser, The Assault Upon the Citadel (Strict Liability to the Consumer), 69 YALE L.J. 1099, 1131-33 (1960) (explaining that the traditional enforcement of warranty disclaimers barred recovery for consumers of defective products in the absence of negligence claims).

16. Dowagiac Mfg. Co. v. Mahon, 101 N.W. 903, 904 (N.D. 1904) (enforcing a limitation of a drill warranty covering only "breakage caused by manifest defects in materials"); Burntisland Shipbuilding Co. v. Barde Steel Prods. Corp., 278 F. 552, 553 (D. Del. 1922) (enforcing complete disclaimer of liability by seller of steel); Helvetia Copper Co. v. Hart-Parr Co., 171 N.W. 272, 274 (Minn. 1919) (enforcing limitation of remedies to repair or refund of purchase price).

17. See Gearing v. Berkson, 111 N.E. 785, 223 Mass. 257, 260 (Mass. 1916) (dismissing a claim for unwholesome pork chops because of "the absence both of an implied warranty and of negligence on the part of the defendants"). 
and the party it was suing in negligence. ${ }^{18}$ This defeated tort claims by consumers who did not directly buy the product from the defendant. Consumer buyers were often left to sue insolvent retailers rather than the deep-pocketed manufacturers who created the defective product. ${ }^{19}$

The adoption of strict liability for defective products came as a response to the perception that the limitations of traditional negligence and warranty law imposed too great of a burden on consumers. ${ }^{20}$ Courts first began to adopt strict liability in the context of defective or unwholesome foods. ${ }^{21}$ In 1963, the Supreme Court of California held in Greenman v. Yuba Power Products that "[a] manufacturer is strictly liable in tort when an article he places on the market, knowing that it is to be used without inspection for defects, proves to have a defect that causes injury to a human being." 22 The court stated that the doctrine was necessary "to insure that the costs of injuries resulting from defective products are borne by the manufacturers that put such products on the market rather than by the injured persons who are powerless to protect themselves." ${ }^{23}$ After Greenman, the Restatement (Second) of Torts adopted strict liability for the defective products rule in $\S 402 \mathrm{~A} .^{24}$ These two developments prompted states to adopt strict liability for defective products, which eliminated many of the defenses available under traditional negligence and warranty law. ${ }^{25}$ The economic loss doctrine therefore arose in the context of the competing theories of warranty and products liability law, and attempted to draw a line of demarcation between

18. James Jr., supra note 14, at 44 (explaining that courts at the beginning of the 20th century were reluctant to find liability for defective products in the absence of contractual privity).

19. See, e.g., Abercrombie v. Union Portland Cement Co., 205 P. 1118, 1119 (Idaho 1922) (denying recovery to plaintiff who had no "contractual relation" with the manufacturer it sued). See also James Jr., supra note 14, at 44 (explaining that at the beginning of the twentieth century, recovery was "limited to the parties" of a contract, rather than "those who might foreseeably be injured" by use of the defective product).

20. See Prosser, supra note 15, at 1131-33 (stating that the general enforcement of warranty disclaimers in products cases places "dangerous power ... in the hands of the seller"); James Jr., supra note 14, at 44 (stating that the privity requirement helped "protect the manufacturer from burdens on his activity, but it did so at the expense of the victims of his mistakes").

21. Prosser, supra note 15, at 1104 (citations omitted) (explaining that early American courts "imposed strict liability upon the seller of food, in favor of his purchaser, as 'a principle, not only salutary, but necessary to the preservation of health and life"').

22. 377 P.2d 897, 900 (Cal. 1963).

23. Id. at 901.

24. RESTATEMENT (SECOND) OF TORTS § 402A (1965).

25. See Herbert W. Titus, Restatement (Second) of Torts Section 402A and the Uniform Commercial Code, 22 STAN. L. REv. 713, 718 (1970) ("Since the adoption of section 402A in 196[5], it has become increasingly clear that the principal effect of the strict tort liability rule has been the elimination of defenses based on traditional warranty guidelines in products-liability cases."). 
the two. ${ }^{26}$

\section{Seely v. White Motor Co. ${ }^{27}$}

The economic loss doctrine was first officially adopted by the California Supreme Court in the 1965 case of Seely v. White Motor Co. ${ }^{28}$ The plaintiff, Seely, bought a truck manufactured by White Motor Co., and the truck overturned when the brakes malfunctioned. ${ }^{29}$ Although Seely was not physically injured, he brought claims of "breach of express warranty, breach of warranty of fitness for purpose of intended use, breach of contract" and strict liability in tort for the purchase price, lost profits, and repairs to the truck. ${ }^{30}$ Seely initially brought these claims against White Motor Co. and the retailer, Southern Truck Sales, but dismissed the action against Southern. $^{31}$ The California Supreme Court affirmed lower court rulings permitting warranty recovery for the purchase price and lost profits-but not the repairs - and denying tort liability. ${ }^{32}$

In affirming the court of appeals, the supreme court explained the economic loss doctrine:

[Defendant] can appropriately be held liable for physical injuries caused by defects by requiring his goods to match a standard of safety defined in terms of conditions that create unreasonable risks of harm.

26. See, e.g., Koss Const. v. Caterpillar, Inc., 960 P.2d 255, 259-60 (Kan. Ct. App. 1998).

27. 403 P.2d 145 (Cal. 1965) (en banc).

28. Breer \& Pulikkan, supra note 5, at 31 (citing Seely, 403 P.2d at 147-48).

29. Seely, 403 P.2d at 147.

30. Seely v. White Motor Co., 39 Cal. Rptr. 805, 806 (Cal. Ct. App. 1964), vacated, 403 P.2d 145 (Cal. 1965) (en banc); Seely v. White Motor Co., 403 P.2d 145, 147-48 (Cal. 1965).

31. Seely, 403 P.2d at 148.

32. Id. at 152. The California District Court of Appeals affirmed Seely's recovery against White Motor Co. on the purchase price and lost profits because White Motor Co. breached the express warranty. Seely, 39 Cal. Rptr. at 808. At the time of this case California had adopted the UCC, which states that an express warranty is created "if the natural tendency of [an] affirmation of promise is to induce the buyer to purchase the goods, and if the buyer purchases the goods relying thereon.” Seely, 403 P.2d at 148 (citing CAL. CIV. CoDE $\$ 1732$ (repealed 1979)). White Motor Co. limited the express warranty to repair and replacement, and the court found that White breached this warranty by failing to repair the truck. Seely, 39 Cal. Rptr. at 808 . Turning to plaintiff's strict liability claim, the court noted that the trial court failed to make a ruling on this issue. $I d$. at 810 . However, the court held this was not reversible error because product liability claims were recoverable only for personal injury claims. Id. at 812. On appeal, the Supreme Court of California affirmed the court of appeals ruling. Seely, 403 P.2d at 152 . The supreme court first upheld the award of damages for the purchase price and lost profits based on the breach of express warranty, because these losses directly resulted "in the ordinary course of events from the breach of warranty." $I d$. at 148-49. The court also affirmed the denial of Seely's breach of warranty claim for repair costs because Seely failed to show causation. Id. at 152 . 
He cannot be held for the level of performance of his products in the consumer's business unless he agrees that the product was designed to meet the consumer's demands.

In other words, economic losses to the consumer caused by the product's performance in the consumer's business are a matter for agreement, or warranty, while physical injuries are for "a standard of safety" imposed by the law regardless of the agreement. The court worried that if a manufacturer was held strictly liable in tort for economic damages, thereby preventing the manufacturer from defining the scope of its liability through warranty, "[t]he manufacturer would be liable for damages of unknown and unlimited scope." 34 The court therefore held that a plaintiff could recover in tort for physical injury and property damage, but not for "his economic expectations." 35 Applying this doctrine to Seely's claim, the court found that the claim for cost of repairs was for physical damage to the truck, and therefore was recoverable on a strict liability theory. ${ }^{36}$ However, because Seely failed to show "that the defect caused the physical damage [to] the truck," he could not recover on this basis. ${ }^{37}$

Dissenting, Justice Peters argued that because the court found White Motor Co. liable on the breach of warranty claim, it was unnecessary for the court to decide that Seely could not recover on his strict liability claim. ${ }^{38}$ Therefore, Justice Peters argued, "[e]verything said by the majority on that subject is obviously dicta." 39 Despite Justice Peters's concerns, the Seely Court's explanation of the economic loss doctrine has been continuously cited as the first formal adoption of the doctrine. ${ }^{40}$

\section{The Impact of the Concern for Unlimited Liability}

A line of cases before Seely dealt with the potential for unlimited

\footnotetext{
33. Seely, 403 P.2d at 151.

34. Id. at $150-51$.

35. Id. at 152 .

36. $I d$.

37. Id.

38. Id. at 153 (Peters, J., dissenting) ("The majority, having found in favor of the plaintiff on the theory of an express warranty, completely decided the case. There was no need to discuss the strict liability doctrine.").

39. Id.

40. See Neibarger v. Universal Coops., Inc., 486 N.W.2d 612, 618 (Mich. 1992) (referring to Seely: "the decision [is] generally regarded as the genesis of the doctrine"); Vincent R. Johnson, The Boundary-Line Function of the Economic Loss Rule, 66 WASH. \& LEE L. REV. 523, 585 (2009) (stating that " $[\mathrm{t}] \mathrm{he}$ branch of the rule denying compensation under tort law for harm caused by defective products originated with Seely").
} 
liability, and this theme later fueled the concern for unlimited liability in economic loss cases like Seely. ${ }^{41}$ One of the earliest examples was the 1866 case of Ryan v. New York Central Railroad Co., involving the negligent spreading of a fire. ${ }^{42}$ This case focused primarily on proximate cause, but there was a strong undercurrent of concern for the unlimited liability that would ensue if law attempted to hold the negligent tortfeasor liable for all harms to property:

A man may insure his own house or his own furniture, but he cannot insure his neighbor's building or furniture, for the reason that he has no interest in them. To hold that the owner must not only meet his own loss by fire, but that he must guarantee the security of his neighbors on both sides, and to an unlimited extent, would be to create a liability which would be the destruction of all civilized society ${ }^{43}$

Fear of unlimited liability in economic loss cases continued after Seely. Courts felt that allowing tort recovery — or even recovery without privity-in cases of economic loss would lead to liability on an unmanageable scale. ${ }^{44}$ The 1968 negligence case Kinsman II involved a cargo ship that broke free from its moorings, struck a second ship, and crashed into a bridge, causing flooding when the two ships and the bridge formed a dam. ${ }^{45}$ The court denied recovery to plaintiffs, holding that the economic losses they incurred as a result of the flooding - based on an inability "to move traffic along the river"-were too remote from the negligence. ${ }^{46}$ The court reasoned that the prevention of unlimited liability required it to draw a line barring claims that were "too tenuous and remote to permit recovery." 47 Courts have continued to cite the policies of unlimited liability and foreseeability as a driving factor in not allowing tort recovery for economic losses. ${ }^{48}$ In contrast, courts have less concern about unlimited liability for economic loss in warranty actions

\footnotetext{
41. Seely, 403 P.2d at 150-51 (discussing the concern for unlimited liability).

42. 35 N.Y. 210 (N.Y. 1866).

43. Id. at $216-17$.

44. Nobility Homes of Tex., Inc. v. Shivers, 557 S.W.2d 77, 82 (Tex. 1977) (“Courts which have declined to overturn the privity requirement in warranty actions for economic loss have reasoned that ... holding manufacturers liable for economic loss imposes unlimited and unforeseeable liability upon manufacturers.").

45. In re Kinsman Transit Co., 388 F.2d 821, 822-23 (2d Cir. 1968).

46. Id. at $824-25$.

47. $I d$.

48. See, e.g., S.A.I., Inc. v. Gen. Elec. Railcar Servs. Corp., 935 F. Supp. 1150, 1155 (D. Kan. 1996) ("The economic loss doctrine serves to protect against infringement of the remedies that have been articulated by the Uniform Commercial Code, as well as to guard the manufacturer against unlimited liability in its manufacture of products.").
} 
because defendants can limit their liability in the terms of the warranty. ${ }^{49} \mathrm{~A}$ warranty defendant subject to unlimited liability has, in a sense, only itself to blame for its failure to anticipate that risk and draft the warranty accordingly.

\section{East River S.S. Corp. v. Transamerica Delaval Co.}

In 1986, the United States Supreme Court adopted the economic loss doctrine in East River S.S. Corp. v. Transamerica Delaval, Inc. ${ }^{50}$ East River, charterers of a supertanker, brought an action against Transamerica Delaval for negligence, strict liability, breach of contract and breach of warranty after a turbine installed by Transamerica malfunctioned. ${ }^{51}$ The only damage was to the turbines themselves. ${ }^{52}$ After Transamerica submitted a statute of limitations defense, East River amended its complaint and brought only the negligence and strict liability claims. ${ }^{53}$ Therefore, the Court had to "decide whether a cause of action in tort is stated when a defective product purchased in a commercial transaction malfunctions, injuring only the product itself and causing purely economic loss. $" 54$

The East River Court explained the spectrum of holdings on economic loss cases at the time. A majority of courts had adopted the economic loss doctrine, denying recovery in tort for claims of purely economic loss. ${ }^{55} \mathrm{~A}$ minority of courts had allowed economic loss recovery based on the theory that a distinction between physical and economic damage is "arbitrary." 56 Finally, some courts took "intermediate positions" and allowed recovery for economic losses when the product created an unreasonable risk of harm but did not cause physical injury. ${ }^{57}$ The Supreme Court rejected both the minority and intermediate approaches and adopted the economic loss doctrine, because the intermediate approach prevented business managers from properly allocating risk and the minority approach failed to

\footnotetext{
49. See, e.g., Seely v. White Motor Co., 403 P.2d 145, 151 (Cal. 1965) (explaining that "[a]pplication of the rules of warranty prevents" the problem of a manufacturer being unable to define its scope of legal responsibility).

50. 476 U.S. 858 (1986).

51. Id. at 861 .

52. Id.

53. Id.

54. Id. at 859 .

55. Id. at 868 .

56. Id. at 869 .

57. Id. at 870 .
} 
contemplate limits on product liability actions. ${ }^{58}$

However, the Court stated that a main reason for adopting the economic loss doctrine was to prevent the deterioration of the line between warranty and tort law. ${ }^{59}$ The Court continued to emphasize this theme throughout its opinion. ${ }^{60}$ At one point, the Court famously declared that, without the economic loss doctrine, "contract law would drown in a sea of tort." Therefore, the Court adopted the following doctrine: "whether stated in negligence or strict liability, no products-liability claim lies in admiralty when the only injury claimed is economic loss. ${ }^{, 62}$

Although the East River Court emphasized the distinction between tort and warranty law as its main reason for adopting the economic loss doctrine, it discussed other policy factors that influenced its decision. First, the Court highlighted the business nature of the transaction, as opposed to a consumer transaction, as a reason society had a lesser interest in ensuring the buyer's recovery beyond the terms of a warranty. ${ }^{63}$ The Court also stated its concern with the potential for unlimited liability without the economic loss doctrine. ${ }^{64}$ Finally, the Court found that adoption of the doctrine promoted efficient bargaining between parties, especially when the parties held equal bargaining power. ${ }^{65}$ These secondary policies later influenced the expansion of the doctrine into a variety of contexts.

\section{Expansion of the Doctrine After East River}

After the East River opinion, courts in various jurisdictions quickly adapted the economic loss doctrine to products liability cases outside the admiralty context. ${ }^{66}$ These cases represent the economic loss doctrine at its

\section{Id.}

59. Id. at $870-71$ (citing "the need to keep products liability and contract law in separate spheres and to maintain a realistic limitation on damages" as the most powerful argument).

60. Id. at 866 (citing G. GILMORE, THE DEATH OF CONTRACT 87-94 (1974) (stating that without a limitation on products liability law, "contract law would drown in a sea of tort")).

61. Id.

62. Id. at 876 .

63. Id. at $871-72$ (comparing the societal interest in providing recovery for personal injuries, which may create "overwhelming misfortune," with the interest in providing recovery for a commercial user whose product does not meet contractual expectations).

64. Id. at 874 ("Permitting recovery for all foreseeable claims for purely economic loss could make a manufacturer liable for vast sums.").

65. Id. at 873 ("While giving recognition to the manufacturer's bargain, warranty law sufficiently protects the purchaser by allowing it to obtain the benefit of its bargain.").

66. E.g., REM Coal Co., Inc. v. Clark Equip. Co., 563 A.2d 128, 132 (Pa. Super. Ct. 1989) (" $[\mathrm{W}] \mathrm{e}$ adopt the standard unanimously adopted by the Supreme Court in [East River], under which recovery in tort is barred in product liability actions between commercial enterprises where the only 
most basic level. Courts have recognized that the origins of the doctrine are traced to business - as opposed to consumer-products liability cases and that many contemporary cases apply the doctrine in the business products liability context. ${ }^{67}$ In addition, courts began to expand the doctrine beyond this context based on the policies set forth in East River and other early cases.

First, courts extended the economic loss doctrine to deny recovery in cases in which a product caused damage to a purchaser's property, as in East River. $^{68}$ These courts reasoned that, if the damage was within the contemplation of the parties, the proper method of risk allocation was the parties' own bargaining and therefore warranty, not tort, was the proper governing law. ${ }^{69}$

Courts also expanded the doctrine by applying it to the construction context. $^{70}$ Although these cases usually involved claims based on both products and services, the courts found that the policies announced in East River and other early cases applied with equal force. ${ }^{71}$ Many jurisdictions applied the doctrine in cases outside the business context, arguing that the proper distinction was between economic and physical damages rather than business and consumer contracts. ${ }^{72}$ Other courts began applying the doctrine

damage alleged is to the product itself.").

67. E.g., Hydro Investors, Inc. v. Trafalgar Power Inc., 227 F.3d 8, 16 (2d Cir. 2000) (citing Saratoga Fishing Co. v. J.N. Martinac \& Co., 520 U.S. 875 (1997)) (recognizing that "[t]he rule developed as a way of enforcing the dictates of privity in product liability law" and that "the majority of cases enunciating the economic loss rule have arisen in the context of product liability").

68. Neibarger v. Universal Cooperatives, Inc., 486 N.W.2d 612, 619 (Mich. 1992) (economic loss doctrine barred plaintiffs' claims based on allegedly defective milking product that caused injury to plaintiffs' cows); Dakota Gasification Co. v. Pascoe Bldg. Sys., a Div. of Amcord, Inc., 91 F.3d 1094, 1100-01 (8th Cir. 1996) (economic loss doctrine applied to a claim by the owner of a natural gas production plant against a supplier of steel structural components for damage caused to owner's plant).

69. Eric R. Skinner, The Expansion of the Economic Loss Doctrine: Neibarger v. Universal Cooperatives, Inc., 1993 DET. C.L. REV. 1007, 1007-08 (1993) (describing the expansion of the doctrine to situations in which "such damage is found to have been within the contemplation of the parties at the time of bargaining").

70. E.g., Berschauer/Phillips Const. Co. v. Seattle Sch. Dist. No. 1, 881 P.2d 986, 992 (Wash. 1994) (deciding to "maintain the fundamental boundaries of tort and contract law by limiting the recovery of economic loss due to construction delays to the remedies provided by contract").

71. See id. (discussing the concern for unlimited liability as a factor in the court's decision); see also Wausau Paper Mills Co. v. Chas. T. Main, Inc., 789 F. Supp. 968, 974 (W.D. Wis. 1992) (stating that the plaintiff's economic loss through construction services was simply a failure "of the purchaser to receive the benefit of its bargain - traditionally the core concern of contract law").

72. See Roehm v. Charter Mobile Home Moving Co., 907 F. Supp. 1110, 1113 (W.D. Mich. 1993) (citing Kewin v. Mass. Mut. Life Ins. Co., 295 N.W.2d 50, 55 (Mich. 1980)) (noting that the Michigan Supreme Court had previously held that a consumer plaintiff could not bring tort claims for economic losses without allegations and proof of the tortious conduct that is independent of the 
to claims involving negligence and claims within the context of services rather than products. ${ }^{73}$

\section{B. Limitation of the Economic Loss Doctrine Through the Creation of Exceptions}

While some courts continued to expand application of the economic loss doctrine, others began to use the same policies driving expansion to limit the doctrine. For example, the economic loss doctrine does not apply to damage that a product causes to a purchaser's "other property."74 This exception was adopted because courts treat personal injury and property damage alike. $^{75}$ However, the "other property" exception has created significant confusion among courts having to distinguish between the purchaser's "other property" and "component parts" of the product at issue. ${ }^{76}$ Generally, courts have held that something that is part of the integrated structure of an item or is part of the finished product is a "component part" of the product rather than "other property." 77

Additionally, some jurisdictions allow tort recovery in cases involving services rather than products. ${ }^{78}$ According to these courts, the justification for this exception lies with the underlying purposes of warranty and tort law. ${ }^{79}$ Because the UCC sales chapter applies to sales of goods, warranty law is more appropriate where goods are involved, whereas tort law is more

contract breach).

73. See A. Dean Bennett, The "Unique Circumstances" Exception to the Economic Loss Doctrine, ADVOC. (IDAHO), March/Apr. 2009, at 26, 26 (providing that "the rule is now applied in negligence cases where the concept of proximate cause has traditionally been the gatekeeper to a plaintiff's recovery," and is also applied to "the poor performance of services").

74. E. River S.S. Corp. v. Transamerica Delaval, Inc., 476 U.S. 858, 867 (1986) (stating that a manufacturer's duty of care extends to "protection against property damage").

75. Id.

76. See Lynn E. Wagner \& Richard A. Solomon, Finally A Concrete Decision: The Supreme Court of Florida Ends the Confusion Surrounding the Economic Loss Doctrine, 68 FLA. B.J. 46, 52 (1994) ("The 'other' property exception has, perhaps, spawned more debate and confusion than any other issue concerning the economic loss doctrine.").

77. E.g., Bay Breeze Condo. Ass'n, Inc. v. Norco Windows, Inc., 651 N.W.2d 738, 746 (Wis. Ct. App. 2002).

78. See Kalahari Dev., LLC v. Iconica, Inc., 811 N.W.2d 825, 831-32 (Wis. Ct. App. 2012) (stating that if a claim is based more on products than services the economic loss doctrine applies, but if the claim is based more on services the economic loss doctrine does not bar recovery).

79. Linden v. Cascade Stone Co., 699 N.W.2d 189, 193 (Wis. 2005) (stating that the predominant purpose test for distinguishing between products and services was developed in the UCC Article 2 (regulating sales of goods) context). 
applicable in the services context. ${ }^{80}$ Courts also cite the informal nature of service contracts as a reason not to extend the economic loss doctrine to this context. $^{81}$

Some courts also allow tort recovery for economic losses in fraud and negligent misrepresentation claims. Courts generally take one of three approaches when faced with economic loss claims based on fraud. ${ }^{82}$ First, some courts apply the economic loss doctrine in its usual fashion and hold that the defrauded party's claim is solely contract, not tort. ${ }^{83}$ Second, some courts allow tort claims for economic losses in cases of fraud. ${ }^{84}$ Finally, an intermediate rule, adopted by some courts, allows tort recovery when "the fraud is not interwoven with the quality or character of the goods or otherwise involves performance of the contract." ${ }^{" 85}$ Another set of courts also allows tort recovery in cases of negligent misrepresentation. ${ }^{86}$ These courts cite the rationale that because both fraud and negligent misrepresentation may provide bases for liability independent of a contract, the exception should apply to both forms of misrepresentation. ${ }^{87}$ Therefore, the fraud and negligent misrepresentation exceptions place further limitations on the economic loss doctrine.

The independent duty rule acts as another common limitation on the economic loss doctrine. The independent duty rule allows economic loss claims in tort when the duty can be traced to a source other than the parties' contract. $^{88}$ When the duty underlying a claim can be traced to both a

80. See id. (stating that because UCC Article 2 applies to goods, it is necessary to determine whether goods or services are more predominant in a claim); see also Gray, supra note 4, at 1535 (explaining that one argument against applying the economic loss doctrine to services claims is that "there is no equivalent to the Uniform Commercial Code for the interactions of parties in a service industry").

81. See Gray, supra note 4, at 1535 ("[A]pplying the doctrine to limit remedies is discouraged by the fact that many service contracts are oral.”); Ins. Co. of N. Am. v. Cease Elec. Inc., 688 N.W.2d 462, 470 (Wis. 2004) ("Because of the informal circumstances surrounding most oral contracts for services, the policy provisions underpinning the application of the economic loss doctrine do not readily apply.").

82. Ralph C. Anzivino, The Fraud in the Inducement Exception to the Economic Loss Doctrine, 90 MARQ. L. REV. 921, 931 (2007).

83. See id. ("The first approach is to ignore the fraud and the defrauded party's remedy is solely contract, not tort.").

84. See Robinson Helicopter Co., v. Dana Corp., 102 P.3d 268, 272 (Cal. 2004) (finding that "the Court of Appeal erred in its decision because the economic loss rule does not bar [the plaintiff's] fraud and intentional misrepresentation claims").

85. See Anzivino, supra note 82, at 933.

86. Barton, supra note 9, at 1791-92 (explaining that Florida courts do not extend the economic loss rule to claims of misrepresentation).

87. Id. at $1792-93$.

88. See Jacob W. Crouse, Note, A Long Road Ahead: Determining the Application of the 
contractual and tort law source, the plaintiff is limited to warranty remedies. ${ }^{89}$ However, when the duty can be found in tort independent of the parties' contract terms, the plaintiff's economic loss claims are allowed in tort. ${ }^{90}$ For example, if the parties did not include in their contract the duty to refrain from making misrepresentations, the tort duty to do so would apply. The independent duty rule has gained wide acceptance in recent years, ${ }^{91}$ but courts and commentators continue to debate the scope of this exception. ${ }^{92}$

\section{Development of the Economic Loss Doctrine in Kansas}

The Kansas Court of Appeals formally adopted the economic loss doctrine in 1998 in Koss Construction v. Caterpillar, Inc. ${ }^{93}$ The court based its adoption of the doctrine primarily on the application of the doctrine by other jurisdictions and its own view that East River represented a "straightforward" and "predictable" approach. ${ }^{94}$ However, before this formal adoption of the doctrine, several Kansas cases recognized the economic loss doctrine and its policies. ${ }^{95}$ These cases applied the doctrine

Economic-Loss Doctrine to Service Contracts in the Commonwealth of Kentucky, 49 U. LOUISVILLE L. REV. 445, 452-53 (2011) (explaining the Colorado Supreme Court's application of the independent duty rule).

89. See Johnson, supra note 40, at 526-27 ("[T]here is a consensus that the breach of a purely contractual duty is not actionable as a tort if the only consequences are economic losses.").

90. See id. at 539-40 (explaining that application of the independent duty rule means that economic loss claims are barred "[o]nly where a contract expressly or by necessary implication elects to replace tort principles actually or potentially establishing an independent duty"); see also DAN B. DOBBS ET AL., THE LAW OF TORTS $\$ 615$ (2013) (“[T]he tort duty, to be actionable, must not be 'interwoven' with the contract.").

91. See DOBBS ET AL., supra note 90, at $§ 615$ n.10.50 (“This 'independent duty rule' appears to be gaining some momentum.”).

92. See Johnson, supra note 40, at 539-40 (explaining that some courts bar claims based on independent tort duties if the duty relates "to the subject matter of an existing contract, [is] based on the same facts as a breach of contract claim, or involve[s] 'disappointed' commercial expectations related to the contract").

93. Koss Const. v. Caterpillar, Inc., 960 P.2d 255, 260 (Kan. Ct. App. 1998) (“[W]e conclude that a commercial buyer of defective goods cannot sue in negligence or strict liability where the only injury consists of damage to the goods themselves."); David v. Hett, 270 P.3d 1102, 1110 (Kan. 2011) (stating that the Koss Construction court applied the economic loss doctrine "as an issue of first impression").

94. Koss Const., 960 P.2d at 259.

95. See, e.g., Elite Prof'ls, Inc. v. Carrier Corp., 827 P.2d 1195, 1202 (Kan. Ct. App. 1992) (not applying the economic loss doctrine because plaintiff's recovery "is not sought for economic loss" but recognizing "the principle that recovery for economic loss is not available in an action sounding in tort"); Prof'l Lens Plan, Inc. v. Polaris Leasing Corp., 675 P.2d 887, 898-99 (Kan. 1984) ("[I]mplied warranties of fitness and merchantability are not extended to a remote seller or manufacturer of an allegedly defective product, which is not inherently dangerous, for only economic loss.”); Broce-O’Dell Concrete Prods, Inc. v. Mel Jarvis Const. Co., 634 P.2d 1142, 1145 (Kan. Ct. App. 1981) ("If the result is simple economic loss, liability and damages are governed by 
and its policies without explicitly adopting it. ${ }^{96}$ The Koss Construction court's approach can therefore be seen as the explicit adoption of a policy that the Kansas courts had been applying throughout the previous decade.

Like the courts in East River and Seely, the Koss Construction court first adopted the doctrine in the business product liability context. ${ }^{97}$ However, Kansas courts soon extended the doctrine to areas such as consumer purchases, services, and construction. ${ }^{98}$ This expansion set the stage for the courts to consider the limitations of the growing doctrine. This Comment will first discuss expansion of the economic loss doctrine in Kansas, then turn to the limitations imposed on it.

\section{Application in Consumer and Business Products Cases}

In Koss Construction, the plaintiff sued the manufacturer of a vibratory roller after the roller was damaged by a defective part. ${ }^{99}$ The plaintiff sued under theories of breach of implied warranty of merchantability, negligence, and strict liability. ${ }^{100}$ The district court dismissed the breach of warranty claim because Koss Construction lacked privity with Caterpillar. ${ }^{101}$ The district court also dismissed the plaintiff's claims for negligence and strict liability, citing the economic loss doctrine. ${ }^{102}$ In its opinion affirming the district court, the court of appeals noted the persuasiveness of the East River decision and the policy goal of establishing a "logical demarcation between cases properly pursued as tort actions and those which are warranty claims." 103 Because economic losses are "traditionally the core concern of contract law," the court held that such losses should not be recoverable in tort. $^{104}$

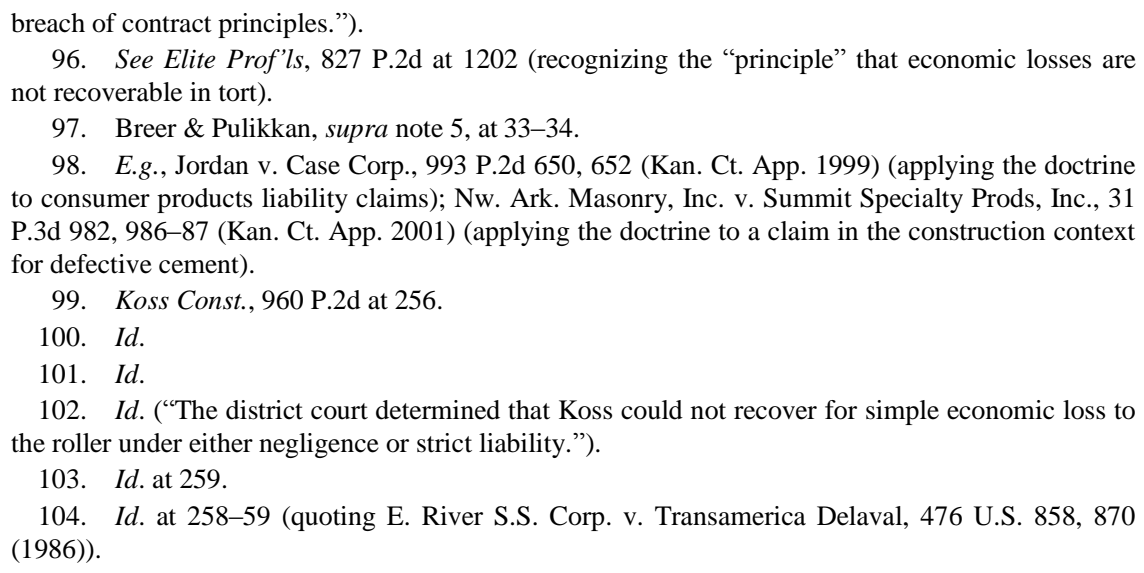

98. E.g., Jordan v. Case Corp., 993 P.2d 650, 652 (Kan. Ct. App. 1999) (applying the doctrine to consumer products liability claims); Nw. Ark. Masonry, Inc. v. Summit Specialty Prods, Inc., 31 P.3d 982, 986-87 (Kan. Ct. App. 2001) (applying the doctrine to a claim in the construction context for defective cement).

99. Koss Const., 960 P.2d at 256.

100. Id.

101. Id.

102. Id. ("The district court determined that Koss could not recover for simple economic loss to the roller under either negligence or strict liability.”).

103. Id. at 259.

104. Id. at 258-59 (quoting E. River S.S. Corp. v. Transamerica Delaval, 476 U.S. 858, 870 (1986)). 
After Koss Construction, the Kansas courts began to expand the economic loss doctrine to other contexts. First, the Kansas Court of Appeals extended the doctrine outside the context of business buyers to consumer product liability claims in Jordan v. Case Corp. ${ }^{105}$ The Jordan case involved claims made by a farmer's insurer when the farmer's combine caught fire because of an engine defect. ${ }^{106}$ The insurer brought claims against the manufacturer based on theories of breach of implied warranty, strict liability, and negligence. ${ }^{107}$ Applying the economic loss doctrine from Koss, the trial court dismissed the insurer's claims. ${ }^{108}$ The court of appeals affirmed the denial of each of the insurer's claims. ${ }^{109}$ The insurer argued that the engine was other property rather than a component part, and therefore the economic loss doctrine should not apply to bar the claim. ${ }^{110}$ However, the court of appeals found that the engine was a component part of the combine, and therefore the doctrine barred the claims. ${ }^{111}$ The court effectively extended the doctrine in two ways. First, it carried the doctrine outside the business context and applied it to a consumer claim. ${ }^{112}$ Second, although the court did not dismiss the other property exception, the court limited its application with its view of the engine as a component part. ${ }^{113}$ This case therefore represented the beginning of the economic loss doctrine's expansion in Kansas.

\section{Application in the Construction Context}

After Jordan, the Kansas courts extended the economic loss doctrine to the construction context through a series of cases. The Kansas Court of Appeals first considered the economic loss doctrine in the construction context in the 2001 case of Northwest Arkansas Masonry, Inc. v. Summit

105. 993 P.2d 650, 652 (Kan. Ct. App. 1999); see also Breer \& Pulikkan, supra note 5, at 34 (explaining that Jordan "extended the economic loss doctrine to include consumer purchases").

106. Jordan, 993 P.2d at 651. This case constituted a consumer claim because the insurer, as the subrogee of Jordan, "stepped into the shoes" of Jordan. See Halpin v. Frankenberger, 644 P.2d 452, 457 (Kan. 1982) ("Subrogation, as the term is defined, contemplates one person stepping into the shoes of another.").

107. Jordan, 993 P.2d at 651.

108. Id.

109. Id.

110. Id.

111. Id. ("We hold that as a matter of law, the Cummins engine was a component part of the combine.").

112. See Nw. Ark. Masonry, Inc. v. Summit Specialty Prods, Inc., 31 P.3d 982, 987 (Kan. Ct. App. 2001) (citing Jordan, 993 P.2d at 651) (describing the effect of Jordan as "expanding the economic loss doctrine to both consumer and commercial purchasers of defective products").

113. Nw. Ark. Masonry, Inc., 31 P.3d at 987-88. 
Specialty Products, Inc. ${ }^{114}$ In Northwest Arkansas, Northwest brought contract and product liability claims against Summit, which allegedly manufactured defective cement powder. ${ }^{115}$ The court considered whether the other property exception applied to the defective cement used by Northwest to build a cement wall. ${ }^{116}$ The court found that in construction cases, an item must be distinguished as other property or part of an "integrated system" of a structure. ${ }^{117}$ If the item is part of an integrated system, then the economic loss doctrine bars the tort claim of damage to the item. ${ }^{118}$ The court noted several cases in other jurisdictions finding that defective cement was part of an integrated system, and then applied the economic loss doctrine to bar Northwest's claim. ${ }^{119}$

The Kansas Court of Appeals next considered the scope of the economic loss doctrine in the construction case Prendiville v. Contemporary Homes, Inc. ${ }^{120}$ In Prendiville, a homeowner brought claims of breach of warranty, negligence, and violation of the Kansas Consumer Protection Act against the project's contractor after a defect caused flooding in the homeowner's basement. ${ }^{121}$ The defendant filed a summary judgment motion, and the district court denied the defendant's motion on the breach of warranty and Consumer Protection Act claims. ${ }^{122}$ The court granted the motion on the negligence claim, citing the economic loss doctrine. ${ }^{123}$ On appeal, the homeowner argued that the economic loss doctrine should not apply for two reasons. ${ }^{124}$ First, the construction of a house constituted a service rather than

114. Id. at 986-87 (framing the issue on appeal as "[w]hether the trial court erred in concluding the economic loss doctrine barred recovery for damages under a strict liability cause of action" for defective cement).

115. Id. at $983-84$.

116. Id. at $987-88$.

117. Id. (explaining that the Restatement (Third) of Torts adopted the integrated systems approach after "[r]ecognizing the difficulty in deciding what constitutes harm to the product itself versus harm to other property").

118. Id. at 988 ("When the product or system is deemed to be an integrated whole ... the damage is excluded from the coverage of this Restatement." (quoting RESTATEMENT (THIRD) OF TORTS: PRODUCTS LIABILITY § 21, cmt. e (1997))).

119. Nw. Ark. Masonry, Inc., 31 P.3d at 988.

120. 83 P.3d 1257 (Kan. Ct. App. 2004), overruled by David v. Hett, 270 P.3d 1102 (Kan. 2011).

121. Id. at $1258-59$.

122. Prendiville v. Contemporary Homes, Inc., No. 00CV1742, 2001 WL 35911172 (Kan. Dist. Ct. Sept. 24, 2001).

123. Id. ("Plaintiff's Count II is barred by the economic loss doctrine, and Defendant's Motion for Summary Judgment on Plaintiff's Count II is granted.").

124. Prendiville, 83 P.3d at 1261-63. 
a product, and therefore the court should allow tort recovery. ${ }^{125}$ Second, the doctrine should not apply in residential cases because of the relative inexperience of the buyers. ${ }^{126}$

The court rejected both arguments. ${ }^{127}$ Although noting a split of authorities outside Kansas on the application of the doctrine to residential construction cases, the court held that the economic loss doctrine applied whether or not the claim was based on a service or product. ${ }^{128}$ It also found that the doctrine should apply equally to residential and business parties, and that, if an exception for homeowners was to be made, it was up to the legislature to do so. ${ }^{129}$ The court focused on the policies underlying the doctrine, such as respecting the bargaining process of the parties:

If Prendiville is allowed to proceed with his negligence claim, this would essentially nullify the express warranty agreed upon by the parties. The warranty specifically allowed Prendiville to make claims regarding defects or deficiencies in the house for 1 year following the issuance of the warranty. The effect of allowing Prendiville to proceed on the negligence claim is to extend the defendants' potential for liability for a greater period of time.

The concern for unlimited liability and the blurring of lines between warranty and tort law fueled the court's extension of the doctrine to this area. The effect of Northwest Arkansas and Prendiville was that the economic loss doctrine in Kansas construction cases applied to a broad range of parties and claims. ${ }^{131}$

\section{ANALYSIS}

Throughout the late 1990s and 2000s, Kansas courts continued to expand the economic loss doctrine into various contexts. ${ }^{132}$ During this

125. Id. at 1261 .

126. Id. at 1263.

127. Id. (noting the plaintiff's arguments and stating "we find no compelling reason why the economic loss doctrine should not be applied to a claim against a contractor in residential construction defect cases").

128. Id. at 1262-63 ("Whether or not a house is deemed to be a 'product,' we find that the principles underlying the economic loss doctrine apply to a residential construction transaction.").

129. Id. at 1263 .

130. Id.

131. See Breer \& Pulikkan, supra note 5, at 34 (concluding that the effect of Northwest Arkansas Masonry and Prendiville is that "Kansas courts do not recognize a cause of action for negligent construction where there is no personal injury or damage to other property").

132. See, e.g., Jordan v. Case Corp., 993 P.2d 650, 652 (Kan. Ct. App. 1999) (applying the doctrine to consumer products liability claims); Nw. Ark. Masonry, Inc. v. Summit Specialty Prods., 
time, Kansas courts applied the economic loss doctrine to all economic loss claims. However, with David v. Hett, Coker v. Siler, and Rinehart v. Morton Buildings, Kansas courts began to limit the reach of the doctrine at least in the home construction context. ${ }^{133}$ These cases effectively halted the expansion of the doctrine, overruled precedent, and opened the door to tort recovery in economic loss home construction cases. ${ }^{134}$ Although the cases properly recognized that the justifications for the economic loss doctrine do not exist in the home construction context, the cases created several problems for future application of the doctrine.

With the advent of tort liability for some economic loss claims in Kansas, these cases introduced several problems for future application of the doctrine. First, it is unclear whether the limitations of these cases will be expanded outside the home construction context. Although reform of the doctrine in other areas does not seem likely now, several problems may arise if the same limitations are applied outside the home construction context. Second, by allowing tort liability for economic loss claims, these cases further complicate the lines between tort and warranty law. Finally, these cases create scope of liability issues regarding which home defect claims should be actionable in tort. The Kansas courts can reduce the potential for these problems by incorporating the independent duty rule and several factors into their economic loss doctrine analysis. The David, Coker, and Rinehart courts touched on the independent duty rule and some of these factors but did not explicitly adopt them. The courts can form a more predictable and accurate analysis by adopting these solutions in future economic loss cases.

\section{A. The Three Kansas Economic Loss Cases}

After more than a decade of the doctrine's expansion, three Kansas cases changed the application of the economic loss doctrine in the home construction context. David v. Hett, Coker v. Siler, and Rinehart v. Morton Buildings, Inc. each allowed tort recovery for economic loss claims in the home construction context. These cases introduced the possibility of tort

\footnotetext{
Inc., 31 P.3d 982, 986-87 (Kan. Ct. App. 2001) (applying the doctrine to a claim in the construction context for defective cement); Prendiville, 83 P.3d 1257 (applying the doctrine to a residential construction defect case).

133. See David v. Hett, 270 P.3d 1102 (Kan. 2011); Coker v. Siler, 304 P.3d 689 (Kan. Ct. App. 2013); Rinehart v. Morton Bldgs., Inc., 305 P.3d 622 (Kan. 2013).

134. See David, 270 P.3d at 1113 (overruling Prendiville); Coker, 304 P.3d at 694 (limiting economic loss doctrine in home construction case); Rinehart, 305 P.3d at 631 (holding that economic loss doctrine does not bar negligent misrepresentation in home construction context).
} 
liability for economic loss claims in at least one context and began discussing exceptions to the doctrine that might limit its application in other contexts.

\section{David v. Hett}

In 2011, the Supreme Court of Kansas reconsidered the economic loss doctrine in the home construction context in David v. Hett. ${ }^{135}$ In David, the homeowners brought claims of "breach of contract, negligence, fraud, fraudulent concealment, and violation of the Kansas Consumer Protection Act" against their contractor after they experienced settling in their home. ${ }^{136}$ The district court granted summary judgment in favor of the contractor on all claims. ${ }^{137}$ The court found that the statute of limitations barred the homeowners' contract and Consumer Protection Act claims and that the homeowners failed to prove the elements of their fraud claims. ${ }^{138}$ The district court held that the economic loss doctrine barred the negligence claim, and the Kansas Court of Appeals affirmed. ${ }^{139}$ Before David, the bright-line rule established in Prendiville barred economic loss claims in construction cases. ${ }^{140}$ The David court reversed this rule and held that the economic loss doctrine did not bar homeowners' claims against a contractor for negligently performed construction services. ${ }^{141}$ The court explained several policy reasons for allowing tort recovery of economic losses in residential construction cases. ${ }^{142}$

First, the David court addressed the policy rationale that warranty remedies are sufficient when the only damage is to a product itself. ${ }^{143}$ The court emphasized the nature of the claim in this case as involving a service rather than a product, and found this distinction important in light of the

\footnotetext{
135. David, 270 P.3d 1102.

136. Id. at 1104 .

137. Id.

138. Id.

139. Id

140. Prendiville v. Contemporary Homes, Inc., 83 P.3d 1257, 1264 (Kan. Ct. App. 2004) ("We hold the economic loss doctrine recognized in Kansas in [Koss Construction] and subsequent cases applies to a claim against a contractor in residential construction defect cases where the rights and liabilities of the parties are governed by contract and an express warranty."), overruled by David, 270 P.3d 1102.

141. David, 270 P.3d at 1114 ("[W]e overrule the Prendiville court's extension of the doctrine to homeowners' claims against a residential contractor.").

142. Id. at 1113 ("We find these policy rationales do not readily apply to parties to a home construction contract and should not cause us to revise our existing caselaw.").

143. Id.
} 
warranty policy. ${ }^{144}$ The court explained that, although this policy seemed appropriate in the context of products cases, it was inappropriate for services cases. ${ }^{145}$ The Kansas Uniform Commercial Code for sales applies "to transactions in goods, not services," and because of this the court found that warranty law did not provide a remedy for services claims. ${ }^{146}$ The court therefore recognized the services exception as an effective limitation on the economic loss doctrine without explicitly adopting it. ${ }^{147}$ Additionally, the court found that the exception's rationale "is easily applied to residential construction contracts such as the one at issue in this case."148

Several jurisdictions have endorsed this view and allowed tort recovery for services - especially professional services-in economic loss cases. ${ }^{149}$ However, a significant number of courts have expressly rejected the services exception as an inadequate basis for distinction in economic loss cases. ${ }^{150}$ These courts find that the economic loss doctrine has just as high an interest in precluding services tort claims - at least professional services tort claims - as it does precluding products tort claims. ${ }^{151}$ This argument seems to have significant weight in Kansas. Although services are not explicitly covered by the Kansas Uniform Commercial Code, most services are covered by warranty law through the duty to perform services "in a workmanlike manner." 152 However, the implied warranty to perform services in a workmanlike manner does not apply in Kansas to all services, such as professional services by a doctor or lawyer, so tort recovery for

\footnotetext{
144. Id.

145. Id.

146. Id.

147. Id. at 1113-14 (noting the services exception as one reason for not applying the economic loss doctrine and stating "several jurisdictions have found the economic loss doctrine is not well suited for contracts to supply services").

148. Id. at 1114.

149. See, e.g., Ins. Co. of N. Am. v. Cease Elec., Inc., 688 N.W.2d 462, 472 (Wis. 2004) (holding that the "economic loss doctrine is inapplicable . . f for the negligent provision of services"); Cargill, Inc. v. Boag Cold Storage Warehouse, Inc., 71 F.3d 545, 550 (6th Cir. 1995) (doctrine applies to transaction in goods, not services); McCarthy Well Co., Inc. v. St. Peter Creamery, Inc., 410 N.W.2d 312, 315 (Minn. 1987) (holding that the economic loss doctrine does not apply if the contract is not governed by the UCC).

150. See Ins. Co., 688 N.W.2d at 467 ("As one treatise noted, "[t]he judiciary remains hopelessly divided on whether the doctrine should be extended to services."').

151. EBWS, LLC v. Britly Corp., 928 A.2d 497, 508 (Vt. 2007) (holding that in the absence of a professional relationship, "there was no special duty of care created beyond the terms of the construction contract and no exception to the economic-loss rule applies").

152. See Zenda Grain \& Supply Co. v. Farmland Indus., Inc., 894 P.2d 881, 890 (Kan. Ct. App. 1995) ("The law in Kansas and, indeed, the general rule throughout the United States is that there is 'implied in every contract for work or services a duty to perform it skillfully, carefully, diligently, and in a workmanlike manner."').
} 
economic loss caused by these services may be appropriate. ${ }^{153}$ In the absence of warranty law in these professional services cases, tort recovery may be justified. Although the services exception may not be an adequate basis for distinction in itself, it can still help define the line between tort and warranty law.

The David court also addressed the nature of the homeowners' claim in light of the warranty rationale. ${ }^{154}$ The court stated that because home defects are often discovered after the warranty time period has expired, warranty law offers little protection to homeowners. ${ }^{155}$ Because of these reasons, the court found that the warranty rationale for the doctrine did not apply in this case. ${ }^{156}$ This conclusion marks a sharp contrast from that in Prendiville, where the court did not even consider the statute of limitations that warranty law imposes. ${ }^{157}$

The court next considered the policy of promoting bargaining among parties in the home construction context. ${ }^{158}$ The court found this policy inapplicable to residential construction cases because of the often-disparate bargaining positions of the parties. ${ }^{159}$ The court found that applying the doctrine in this case would unilaterally benefit the contractor. ${ }^{160}$ Therefore, the court found the nature of the contract-between a consumer and a business - important in determining the applicability of the doctrine. ${ }^{161}$ This conclusion also diverges from Prendiville, where the court rejected the homeowner's argument that due to "the inexperience of a buyer in negotiating contracts, a buyer should not be precluded from maintaining a negligence action against a contractor." 162

Finally, the court found the economic loss doctrine's focus on

153. Tamarac Dev. Co. v. Delamater, Freund \& Assocs., P.A., 675 P.2d 361, 365 (Kan. 1984) (explaining that "it can be said certain professionals, such as doctors and lawyers, are not subject" to the implied warranty to perform services in a workmanlike manner, but can be liable in tort for malpractice).

154. David v. Hett, 270 P.3d 1102, 1114 (Kan. 2011).

155. Id.

156. Id. (stating that the court rejects the warranty rationale and other reasons used by Prendiville to justify application of the economic loss doctrine).

157. See generally Prendiville v. Contemporary Homes, Inc., 83 P.3d 1257 (Kan. Ct. App. 2004), overruled by David, 270 P.3d 1102.

158. David, 270 P.3d at 1114.

159. Id. ("[C]ontracts governing residential construction rarely involve the sophisticated parties with equal bargaining positions present in commercial products cases.").

160. Id.

161. Id. ("The doctrine's application in this context would unequally benefit the contractor.").

162. Prendiville, 83 P.3d at 1263. 
consequences troubling in the residential construction context. ${ }^{163}$ Under the doctrine, a contractor would be liable in tort only if an economic harm turned into a physical injury. ${ }^{164}$ Tort liability under the doctrine simply turns on a matter of timing. ${ }^{165}$ A homeowner who discovers a construction defect pre-injury will save her contractor from tort liability. ${ }^{166}$ This conclusion indicates that the court considered the gravity of harm that a defect causes, even if the defect ultimately causes only economic loss. This analysis was also missing in previous economic loss cases in Kansas. ${ }^{167}$ For these policy reasons, the supreme court overruled Prendiville's application of the economic loss doctrine to residential construction claims. ${ }^{168}$

\section{Coker v. Siler}

The Kansas Court of Appeals solidified the David holding in the 2013 case of Coker v. Siler. ${ }^{169}$ Coker involved a claim by a homeowner after a water line separated and caused cracking in the home's foundation and walls. ${ }^{170}$ The homeowner sued the seller of the home for breach of express warranty and sued the plumber who caused the damage for negligence. ${ }^{171}$ The district court dismissed the claim against the plumber based on the economic loss doctrine. ${ }^{172}$ The court of appeals reversed the dismissal and reiterated the reasoning in David, holding that the homeowner's negligence claim against the plumber was not barred by the economic loss doctrine. ${ }^{173}$ Therefore, even though the terms of the contract might have prevented the homeowner from seeking various remedies, the homeowner would be able to recover from the construction company if the homeowner could prove a breach of a duty "independent of the underlying construction contract." 174

163. David, 270 P.3d at 1114 ("Finally, we agree with the analysis in Kennedy in which the South Carolina Supreme Court found the economic loss doctrine's application to home construction troubling because it focused on the consequence or damages, rather than the duty breached.").

164. Id.

165. Id. (" $[\mathrm{O}]$ ne contractor could be lucky enough to escape liability because the negligence was discovered before someone was harmed.").

166. Id. (stating that under the doctrine a contractor can "escape liability because the negligence was discovered before someone was harmed").

167. See generally Prendiville, 83 P.3d 1257 (considering the type of injury created rather than the harm created).

168. David, 270 P.3d at 1114.

169. Coker v. Siler, 304 P.3d 689 (Kan. Ct. App. 2013).

170. Id. at 692 .

171. Id. at 691 .

172. Id.

173. Id. at 694-95 (citing David in applying the economic loss doctrine).

174. Id. at 695 . 
Because the court found that the plumber who installed the water line owed the homeowner an independent legal duty "to perform plumbing services without causing economic injury to third parties," the court allowed the homeowner's negligence claim against the plumber. ${ }^{175}$ As discussed above, courts in various jurisdictions have adopted this independent duty analysis in economic loss cases. ${ }^{176}$ However, in previous Kansas cases the courts did not consider whether there was a tort duty independent of the terms of a contract. ${ }^{177}$

\section{Rinehart v. Morton Buildings, Inc.}

The Supreme Court of Kansas next reconsidered the economic loss doctrine in the 2013 case of Rinehart v. Morton Buildings, Inc. In Rinehart, the owners of a building sued the construction company on theories of breach of contract, breach of warranty, violation of the Kansas Consumer Protection Act, and negligent misrepresentation. ${ }^{178}$ The owners planned to use the building both as a home and for their cellophane slitting business, but they claimed that the contractor "misrepresented that the building complied with the plans and specifications." 179 The jury awarded damages to the owners on each of the theories. ${ }^{180}$ The supreme court held that the economic loss doctrine does not apply to negligent misrepresentation claims. ${ }^{181}$ The court explained economic loss recovery in negligent misrepresentation claims based on the same rationale in David - that warranty law does not govern or provide an adequate remedy for negligent misrepresentation claims. ${ }^{182}$ The court also stated that the effect of applying the doctrine in this case would be that parties would need to "enter a contract or risk having no rights at all." ${ }^{\text {"183 }}$ Finally, the court found that, because negligent misrepresentation claims already have built-in limitations on liability, it is not necessary to apply the doctrine to these cases to restrict

175. Id. at 696 .

176. E.g., Crouse, supra note 88 , at 452-53 (explaining the Colorado Supreme Court's application of the independent duty rule).

177. See Prendiville v. Contemporary Homes, Inc., 83 P.3d 1257, 1262-64 (Kan. Ct. App. 2004) (citing a case that did not apply the economic loss rule because of an independent tort duty, but rejecting that conclusion); Nw. Ark. Masonry, Inc. v. Summit Specialty Prods., Inc., 31 P.3d 982 (Kan. Ct. App. 2001); Koss Const. v. Caterpillar, Inc., 960 P.2d 255 (Kan. Ct. App. 1998).

178. Rinehart v. Morton Bldgs., Inc., 305 P.3d 622, 625 (Kan. 2013).

179. Id.

180. Id.

181. Id. at 632 .

182. Id

183. Id. 
downstream liability. ${ }^{184}$ For these reasons the court adopted the bright-line rule that the economic loss doctrine does not bar negligent misrepresentation claims. ${ }^{185}$

David, Coker, and Rinehart represent a marked shift in approach to the economic loss doctrine. For the first time since the doctrine's adoption in Kansas, the courts held that the doctrine did not apply to cases in which the plaintiffs claimed only economic losses. The courts also for the first time endorsed several exceptions and policies that limit the doctrine. David and Coker recognized the independent duty rule and the bargaining positions of the parties, and Rinehart adopted the bright-line rule that the doctrine does not apply to negligent misrepresentation claims. ${ }^{186}$ These cases opened the door to tort liability for economic loss claims at least in the residential construction context and raised issues as to the scope of liability allowed when only economic loss is claimed.

\section{B. The Impact of the Three Kansas Cases}

David, Coker, and Rinehart opened the door to tort liability in home construction economic loss cases in Kansas. Although the cases reached the correct conclusion in limiting the doctrine in the home construction context, this new approach creates problems for application of the doctrine in future cases.

\section{The Kansas Courts Appropriately Limited the Economic Loss Doctrine in the Home Construction Context}

These three cases properly limited the economic loss doctrine's application to the home construction context. The justifications for the economic loss doctrine do not exist in the home construction context. First, the nature of home construction claims is not well suited for the economic loss doctrine. ${ }^{187}$ Warranty claims are not subject to the discovery rule. ${ }^{188}$

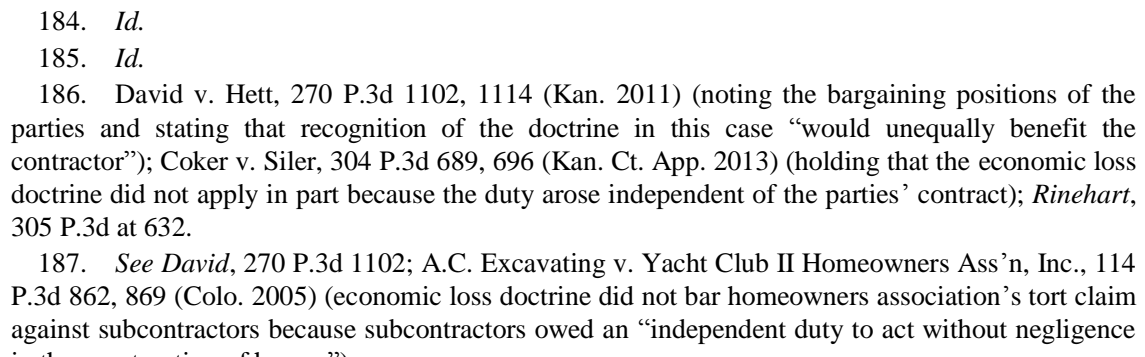

187. See David, 270 P.3d 1102; A.C. Excavating v. Yacht Club II Homeowners Ass'n, Inc., 114 P.3d 862, 869 (Colo. 2005) (economic loss doctrine did not bar homeowners association's tort claim against subcontractors because subcontractors owed an "independent duty to act without negligence in the construction of homes"). 
Therefore, home construction defects that cause only economic loss and are discovered after the warranty statute of limitations expires are not actionable. Second, as the court in David recognized, homeowners are typically inexperienced in negotiating the terms of a warranty. ${ }^{189}$ Homeowners should not be prevented from bringing common law negligence claims that are not covered by the terms of their warranty. Finally, home construction claims often arise from conduct outside the terms of the parties' contract. ${ }^{190}$ When this occurs, courts should not prevent a homeowner's independent negligence claims. For these reasons, the courts in David, Coker, and Rinehart properly found that the economic loss doctrine should not apply in home construction cases.

\section{Problems the Recent Kansas Cases Created for Future Application of the Doctrine}

The addition of David, Coker, and Rinehart to the economic loss doctrine landscape creates three distinct problems for future application of the doctrine in Kansas. First, it is unclear whether the courts intended to alter-by placing limitations on-the economic loss doctrine only in residential construction cases, or whether these cases signal the beginning of tort claims for economic loss in other contexts. The limitations these cases imposed on the doctrine cannot be applied as easily outside the home construction context, and allowing tort recovery in economic loss cases in other contexts may create scope of liability problems. Second, these cases seem to further complicate the distinction between warranty law and tort law claims. Finally, the scope of liability as to the types of home defects recoverable in tort creates problems for analysis of home construction economic loss claims.

\section{a. Problems Related to Limiting the Doctrine Outside the Home Construction Context}

At first glance, the holdings in David, Coker, and Rinehart seem relatively limited. David and Coker allow tort recovery of economic loss in

188. KAN. STAT. ANN. § 60-513 (1963) (defining the discovery rule and listing causes of action subject to discovery rule); 3 AMERICAN LAW OF PRODUCT LIABILITY § 47:27 (1987) (explaining that warranty causes of action are not subject to tolling of statute of limitations except where warranty provides for future performance).

189. David, 270 P.3d at 1114.

190. Coker, 304 P.3d at 695-96 (remanding case for determination whether the defendant's duty arose independent of the parties' contract). 
home construction service projects, and Rinehart allows such recovery in negligent misrepresentation claims within the same context. Each case is limited to the home construction context and does not explicitly alter the economic loss doctrine outside this context. However, it is unclear whether these limitations to the doctrine may in the future be applied outside the home construction context, and Rinehart explicitly leaves this question open. ${ }^{191}$ If the courts begin to limit the economic loss doctrine outside the home construction context, the reasoning used by the recent cases for such limitations breaks down and potential problems with scope of liability arise.

In David and Coker, the courts addressed the economic loss issue in the context of services contracts involving homeowners. ${ }^{192}$ These cases should, therefore, be viewed as limited to this context. If the cases are truly limited in this way, there is support for a professional services exception or a distinction based on consumers in the context of home construction cases. ${ }^{193}$ The David and Coker courts each stated the rationales for excluding liability in these contexts-services are not covered by warranty law in Article 2 of the UCC and consumers typically have less bargaining power than business parties in the same situations. ${ }^{194}$ Therefore, the courts' decisions seem logical when viewed in light of these exceptions.

However, if the Kansas courts alter their approach to the economic loss doctrine outside the context of residential construction cases, the exceptions that the courts rely on break down. In residential construction cases, it is already difficult to justify a distinction on the basis of differences between consumers and business parties. Some cases, including Rinehart, involve parties that could be characterized as either consumers or business entities. ${ }^{195}$ If the courts begin to limit the doctrine in business transactions based on the same rationale, it can be even more difficult to make straightforward rules based on bargaining power because of the disparities in

191. Rinehart, 305 P.3d at 633 ("We leave for another day whether the doctrine should extend elsewhere.").

192. David, 270 P.3d at 1103 (economic loss claim involving service contract for excavation, basement, and concrete work); Coker, 304 P.3d at 691 (negligence claim based on service contract for plumbing work).

193. See 1325 N. Van Buren, LLC v. T-3 Grp., Ltd., 716 N.W.2d 822, 832 (Wis. 2006) (citing Ins. Co. of N.A. v. Cease Elec. Inc., 688 N.W.2d 462, 465 (Wis. 2004)) ("If the contract is purely a service contract, the economic loss doctrine does not apply."); see also Gary M. Victor, The Economic Loss Doctrine and Consumers, МicH. B. J., Sep. 2010, at 23 (describing reluctance of courts to apply the doctrine to consumers in fraud cases and other contexts).

194. David, 270 P.3d at 1113-14; Coker, 304 P.3d at 694.

195. Rinehart, 305 P.3d at 625 (explaining that the plaintiffs planned to use the structure as both their home residence and business location). 
bargaining power between smaller companies and large corporations. ${ }^{196}$ Although the nature of the parties may be a proper distinction for application of the doctrine in the home construction context, this distinction is less useful in other contexts. Therefore, the rule explained in David and Coker seems simple at first, but quickly becomes more convoluted when applied to different sets of facts.

Allowing tort recovery for economic loss cases outside the home construction context also might create problems regarding the scope of tort liability. In the business context, economic damages can affect many parties. A negligently constructed foundation affects everyone in an office building, and pipes that burst in a strip mall might flood multiple businesses. In home construction cases usually only one party - the homeowner-brings a tort claim, thereby naturally limiting the potential sphere of liability. But the same cannot be said in the business context, and therefore the economic loss doctrine cannot as easily be limited in this area. Although the courts did not expressly state that they were prepared to expand the limitations outside the residential construction context, the courts did leave this question unanswered.

\section{b. Blurring of Lines Between Warranty and Tort Law}

These three cases effectively changed the way economic loss construction claims are viewed in Kansas. Each held that the specific economic loss claims might be recoverable in tort. ${ }^{197}$ Courts and commentators have struggled for decades to delineate the line between warranty and tort law, and there likely is no clear line between the two. ${ }^{198}$ However, in product and construction cases tort law has typically been

196. See Daniel D. Barnhizer, Inequality of Bargaining Power, 76 U. CoLo. L. REv. 139, 142 (2005) (stating that the concept of bargaining power "imposes substantial costs upon actors who are traditionally viewed as possessing bargaining power, including small businesses and middle-class consumers").

197. See David, 270 P.3d at 1115 (remanding for lower court to determine whether claim arises in tort or contract); Coker, 304 P.3d at 695 ("Coker's tort claims will survive only if Coker can establish that Chaney owed Coker a duty imposed by law."); Rinehart, 305 P.3d at 627 (acknowledging plaintiff's negligent misrepresentation tort claim).

198. See Cent. Sav. \& Loan Ass'n v. Stemmons Nw. Bank, N.A., 848 S.W.2d 232, 238 (Tex. App. 1992) ("[I]t is often difficult in practice to determine whether a plaintiff's cause of action sounds in contract or tort."); Catherine Paskoff Chang, Two Wrongs Can Make Two Rights: Why Courts Should Allow Tortious Recovery for Intentional Concealment of Contract Breach, 39 COLUM. J.L. \& SOC. PROBS. 47, 56 (2005) (noting the "frequent difficulty in distinguishing between tort and contract claims"); Michael Dorff, Attaching Tort Claims to Contract Actions: An Economic Analysis of Contort, 28 SETON HALL L. REV. 390, 428 (1997) (stating that "courts often have difficulty distinguishing between tort and contract negligence actions"). 
characterized by its focus on personal or property damage, rather than on economic loss. ${ }^{199}$ This is not to say that tort law has been completely reluctant to address economic losses. ${ }^{200}$ Negligent misrepresentation provides a good example of a cause of action in tort that is primarily concerned with economic losses. ${ }^{201}$ But when economic losses are involved and a claim includes both warranty and tort elements, the economic loss doctrine has attempted to draw a recognizable distinction between the two theories.

In each of these three cases, the claims could have been addressed through contract and were arguably better suited for contract law. ${ }^{202}$ Allowing tort recovery in each of these cases therefore makes the distinction between warranty and tort law more convoluted. Contract law-and by extension, warranty law-focuses on agreements, and its core concern is ensuring that parties receive the benefit of their bargain. ${ }^{203}$ In each of the three recent cases, the parties agreed to the terms of the service to be rendered - the construction or improvement of a house. ${ }^{204}$ After the services were performed, the plaintiffs discovered conditions that did not conform to or were outside the scope of the parties' agreements. The damages in each case were not bodily harm or property damage, but economic losses. ${ }^{205}$ Therefore, these claims were probably more suitable for consideration within the context of warranty law, and the plaintiffs recognized this by

199. See B.E. Witkin ET AL., 6 Witkin, Summary of CALIFornia LaW $§ 1162$ (10th ed. 2005) ("Generally, tort law provides a remedy for construction defects that cause property damage or personal injury."); DAVID G. OwEN ET AL., 2 MADDEN \& OWEN ON PRODUCT LiABILITY § 17:13 (3d ed. 1999) ("[W] hen a product damages only itself, tort law provides no remedy and the action lies in contract; but when personal injury or other property damage occurs, a tort remedy may be appropriate.").

200. See supra Part II.B for a discussion of exceptions to economic loss doctrine.

201. See Glanzer v. Shepard, 135 N.E. 275, 276-77 (N.Y. 1922) (recognizing contract principles but allowing third-party buyer to bring a negligent misrepresentation claim after defendant falsely reported weight of beans); Barton, supra note 9, at 1814 ("A tension emerges between negligent misrepresentation, which allows for the recovery of pecuniary loss, and the economic loss rule, which forbids recovery of economic loss in tort." (internal citations omitted)).

202. Each of the cases involved contract or warranty law claims along with the tort claims. David, 270 P.3d 1102; Rinehart, 305 P.3d 622; Coker, 304 P.3d 689.

203. E. River S.S. Corp. v. Transamerica Delaval, Inc., 476 U.S. 858, 870 (1986).

204. David, 270 P.3d at 1103 (describing the contract between the parties "for the excavation, basement, and concrete work" in the plaintiffs' home); Rinehart, 305 P.3d at 625 (discussing the contract between the parties for construction of a dual-purpose building); Coker, 304 P.3d at 691-92 (describing the agreement between the plaintiff and defendant).

205. David, 270 P.3d at 1104 (damages to footings in home and void under porch caused by construction defects); Rinehart, 305 P.3d at 625 (negligent misrepresentation claim based on the overall condition of the structure); Coker, 304 P.3d at 692 (cracks in home's walls and doors caused by water pipe leak). 
bringing breach of warranty and breach of contract claims in addition to tort claims in each case. ${ }^{206}$

Each of the courts, however, found that the claims were subject to tort analysis in addition to warranty law and contract law analysis. ${ }^{207}$ These findings are correct in that each claim had elements of tort as well as warranty law. But, by preventing the application of the economic loss doctrine, these cases made tort law applicable to economic loss cases in the construction context, which have traditionally been subject to warranty law. These cases opened the door to tort law analysis in the economic loss home construction context, and therefore the courts must now determine which home construction defects tort law is prepared to recognize.

\section{c. The Unlimited Liability Problem in Home Construction Economic Loss Cases}

The main concern with opening up these home construction economic loss claims to tort law analysis is the potential for unlimited liability. Under warranty law, these claims would be subject to whatever limitations are imposed by the warranty. ${ }^{208}$ Under a tort law analysis, however, the courts are free to impose liability whenever a proper basis for fault is found. ${ }^{209}$ This opens the door to liability in a wide range of cases; liability is no longer limited to the terms of the warranty, but to the harms that tort law deems actionable. Whereas the parties might limit liability to certain items within a house through warranties, the rule in these cases allows liability for a leaking roof, a cracked wall, or anything else that is a foreseeable harm. The statutes of limitation in Kansas combined with the nature of residential construction claims curb the concern for unlimited liability as far as time and parties involved, but the scope of liability as far as the type of claims plaintiffs can bring is still unclear.

The potential for unlimited liability is less troubling in these home construction cases for two reasons. First, in Kansas the statute of limitations for torts after discovery is three years, and all claims are limited to ten years,

206. David, 270 P.3d at 1104 (listing breach of contract among plaintiff's claims); Rinehart, 305 P.3d at 625 (noting that jury awarded plaintiffs damages on breach of contract claim at trial); Coker, 304 P.3d at 691 (noting that plaintiff brought both breach of express warranty and negligence claims).

207. See David, 270 P.3d at 1114-15; Rinehart, 305 P.3d at 630-33; Coker, 304 P.3d at 694-96. 208. See Kan. STAT. ANN. § 84-2-316 (2012).

209. See David, 270 P.3d at 1115 (remanding for determination whether an independent tort duty was breached). 
thereby limiting the claims a homeowner can bring to within a decade. ${ }^{210}$ Because of the statute of limitations, the builder does not need to worry about unlimited liability for an indeterminate time. Second, as noted above, the home construction context limits liability in a unique way as to the parties who will bring claims. In the residential context there is typically only one party making a claim, as opposed to other product liability cases, in which multiple buyers might make claims against a manufacturer. Therefore, the concern for extended liability to additional parties is also limited, at least in home construction cases.

However, it is still not clear what kind of claims a party in a construction context can make. If David's holding is interpreted broadly as limiting the economic loss doctrine in all residential construction defect cases, plaintiffs can bring claims in tort for any economic loss in the home construction context. ${ }^{211}$ But this seems to extend the rule too far. Can plaintiffs bring a claim for small defects not addressed in the warranty if the defect is not discovered until eight or nine years after the project's completion? Or is there some sort of limitation the courts can place on these claims to ensure that the most troubling defects, such as cracks in a foundation, are addressed without opening the floodgates to every type of home defect being litigated? The issue therefore becomes not who or when courts want to protect through tort liability, but what claims should be actionable when only economic losses are involved. David, Rinehart, and Coker do not provide a clear answer to this problem, but guidance on the types of economic loss claims that can be brought is essential to balancing the economic loss doctrine with the need for tort protection.

\section{Solutions to the Economic Loss Doctrine Problems in Kansas}

Although the three cases left open the question of whether the courts would limit the doctrine in the same ways outside the home construction context, there is no indication that the courts are prepared to limit the doctrine in these ways now. Therefore, the most pressing problems arise in the residential construction context. The question becomes what kind of defects Kansas courts should allow in the home construction context outside the parties' contract when the only damages are economic losses. David, Coker, and Rinehart found the potential for tort liability based on cracks in a

210. See KAn. Stat. AnN. § 60-513(b) (2012).

211. The court declined to adopt the economic loss doctrine in "disputes between homeowners and their contractors." David, 270 P.3d at 1103 (suggesting that the holding would apply to nearly all economic loss claims in residential construction cases). 
home's foundation and walls and on non-compliance with a contractor's plans that caused problems with doors and foundations. ${ }^{212}$ However, it is not clear in what other situations the courts would impose liability despite the economic loss doctrine. There likely is no easy answer or a clear bright line to help determine the types of claims that should be actionable in tort. But it still may be possible to define a narrow slice of cases in which it is appropriate to apply the discovery rule through tort law to extend the time in which a party can make a claim.

Kansas courts can help prevent scope of liability problems and better define the line between warranty and tort law by adopting several solutions. First, the Kansas courts should adopt the independent duty rule. Second, the courts can apply several factors to determine whether tort liability is appropriate in a given home construction economic loss case. These factors should include the gravity of harm that the defect causes, the bargaining positions of the parties, the nature of the source of the claim as a product or service, and whether the defect created a non-economic risk of harm. David, Coker, and Rinehart addressed the independent duty rule and almost all the factors listed above. ${ }^{213}$ However, they did not expressly adopt these solutions in their analysis of tort liability for the claims. By adopting these solutions, the courts will be able to more easily determine which home construction economic loss claims are recoverable in tort and create a framework for analyzing tort liability in other economic loss contexts.

\section{The Independent Duty Rule}

Kansas courts can help prevent scope of liability problems in economic loss cases by adopting the independent duty rule, which has been adopted in Colorado and other jurisdictions. ${ }^{214}$ As explained above, the independent duty rule bars tort liability when a defendant's duty can be traced to both a

212. David, 270 P.3d at 1104 (stating that the plaintiff sought damages "in order to bring the house into compliance with the plans, specifications and drawings that were originally agreed upon between the plaintiffs and defendant as the proper construction for [the] house"); Rinehart, 305 P.3d at 625 (explaining that the jury "determined Morton willfully misrepresented that the building complied with the plans and specifications and would include anchor bolts, roof fasteners, fire stops, a vapor barrier, and truss repairs"); Coker, 304 P.3d at 692-93.

213. David, 270 P.3d at 1113-14 (discussing the relative bargaining experience of the parties, the nature of the alleged harm, and the suitability of the economic loss doctrine to services contracts); Rinehart, 305 P.3d at 632 (discussing bargaining positions of parties); Coker, 304 P.3d at 695 (analyzing whether the plaintiff's claims arose independent of the parties' contract).

214. See Alma v. AZCO Const., Inc., 10 P.3d 1256, 1264 (Colo. 2000) ("We hold that a party suffering only economic loss from the breach of an express or implied contractual duty may not assert a tort claim for such a breach absent an independent duty of care under tort law."). 
contractual and common law tort source. ${ }^{215}$ The reasoning behind this rule is that it helps define the line between warranty and tort law claims by analyzing the source of the duty. ${ }^{216}$ Kansas courts should adopt the independent duty rule for three reasons. First, it provides a simpler way to determine which claims are appropriate for tort law analysis and those that are more appropriate for warranty law analysis. Second, it would help prevent the potential for unlimited liability in home construction cases by defining the scope of tort law. Finally, it has been recognized by Kansas courts and other jurisdictions as an effective way to distinguish tort and warranty claims.

The independent duty rule provides a simpler, more straightforward analysis than pure application of the economic loss doctrine. The economic loss doctrine, in its purest form, focuses on the damages a claimant seeks. ${ }^{217}$ This may provide a starting point for analysis of whether a claim should be actionable in warranty or tort. ${ }^{218}$ However, some claims, such as negligent misrepresentation, are pure tort claims but focus largely on economic losses. ${ }^{219}$ The independent duty rule focuses on the source of the duty of the claim. ${ }^{220}$ This allows courts to determine whether a claim sounds in contract or tort. Under the independent duty rule, if a claim arises independently in tort, outside the terms of a contract, it is actionable even if it seeks to remedy only economic losses. ${ }^{221}$ Courts and commentators have consistently stated that the purpose of the economic loss doctrine is to help distinguish between tort and warranty claims. ${ }^{222}$ The independent duty rule distinguishes between the two causes of action by locating the source of the duty without barring legitimate tort claims merely because they focus on economic losses.

215. Johnson, supra note 40, at 539-40.

216. Katherine Heaton, Comment, Eastwood's Answer to Alejandre's Open Question: The Economic Loss Rule Should Not Bar Fraud Claims, 86 WASH. L. REV. 331, 349 (2011) (stating that the economic loss doctrine focuses on whether there is a "breach of a tort duty arising independently of the terms of the contract").

217. Alma, 10 P.3d at 1262-63 ("The phrase 'economic loss rule' necessarily implies that the focus of the inquiry under its analysis is on the type of damages suffered by the aggrieved party.").

218. Id. at 1263 .

219. Id.

220. Id. at $1262-63$.

221. See Eastwood v. Horse Harbor Found., Inc., 241 P.3d 1256, 1264 (Wash. 2010) (“[W]hile the harm can be described as an economic loss, it is more than that: it is an injury remediable in tort.").

222. Alma, 10 P.3d at 1262 (stating that the doctrine "serves to maintain a distinction between contract and tort law"); Louisburg Bldg. \& Dev. Co. v. Albright, 252 P.3d 597, 622 (Kan. Ct. App. 2011) (stating that the doctrine serves "as the dividing line between contract and the broader array of tort claims"); see also Christopher Scott D'Angelo, The Economic Loss Doctrine: Saving Contract Warranty Law from Drowning in A Sea of Torts, 26 U. TOL. L. REV. 591, 594 (1995). 
Adoption of the independent duty rule would also help prevent the prospect of unlimited liability in home construction economic loss cases. The independent duty rule prevents tort liability when the same tort duty can be found in the parties' contract. ${ }^{223}$ The only time when tort liability would apply to economic loss claims would be when a term within the contract does not cover the same tort duty. In these cases, the plaintiff would still need to demonstrate the existence of an independent tort duty. ${ }^{224}$ Therefore, tort liability would be limited to economic loss cases in which a contract does not cover a specific duty and an independent tort duty can be found. This narrow window of liability would help reasonably limit the types of cases plaintiffs could bring to those in which a legitimate tort duty could be found.

Kansas courts and other jurisdictions have recognized the soundness of the independent duty rule. In David, the Kansas Supreme Court cited cases from Colorado and Washington that had explicitly adopted the independent duty rule. ${ }^{225}$ The Supreme Court of Colorado adopted the independent duty rule in the 2000 case of Town of Alma v. AZCO Construction Inc. ${ }^{226}$ The court stated:

In these situations where we have recognized the existence of a duty independent of any contractual obligations, the economic loss rule has no application and does not bar a plaintiff's tort claim because the claim is based on a recognized independent duty of care and thus does not fall within the scope of the rule.

In Eastwood v. Horse Harbor Foundation, Inc., the Supreme Court of Washington completely substituted the independent duty rule analysis for the economic loss doctrine analysis. ${ }^{228}$ The court found that the relevant question was not whether economic losses were claimed as damages, but rather "whether the injury is traceable also to a breach of a tort law duty of care arising independently of the contract." ${ }^{, 22}$ In David, the Kansas

223. David v. Hett, 270 P.3d 1102, 1108 (Kan. 2011) (citing Alma, 10 P.3d at 1264) (explaining that under the independent duty rule, "a party suffering only economic loss from the breach of an express or implied contractual duty may not assert a tort claim for such a breach absent an independent duty of care under tort law").

224. David, 270 P.3d at 1115 (remanding case to determine whether the plaintiffs "specifically asserted any independent duty").

225. Id. at 1108 (citing Alma, 10 P.3d 1256; Eastwood, 241 P.3d 1256).

226. Alma, 10 P.3d at 1262 n.8 ("[W]e believe that a more accurate designation of what is commonly termed the 'economic loss rule' would be the 'independent duty rule."').

227. Id. at 1263 .

228. Eastwood, 241 P.3d at 1268.

229. Id. at 1264. 
Supreme Court recognized the merit of the rule, but did not expressly adopt the independent duty rule for all economic loss cases. ${ }^{230}$ The court did, however, remand the case for consideration whether the tort claims arose independently from the parties' contract. ${ }^{231}$ The David court recognized that the independent duty rule provided a similar analysis to the approach it had taken in other economic loss cases. ${ }^{232}$ The Coker court also seemed to implicitly adopt this rule by requiring the plaintiff to demonstrate the existence of an independent duty to prevent application of the economic loss doctrine. $^{233}$ Although the Kansas Supreme Court has not explicitly adopted the independent duty rule, the Kansas courts have discussed the independent duty rule favorably and the rationales they have used are very similar to the independent duty rule. ${ }^{234}$

Kansas courts should adopt the independent duty rule as a way to simplify the economic loss doctrine and avoid the potential for unlimited liability in home construction cases. The independent duty rule provides a straightforward approach to economic loss cases that focuses on the source of a warranty or tort duty rather than damages. The rule could also help prevent unlimited liability by making liability dependent on the plaintiff finding a duty outside the terms of the parties' contract. Kansas courts have already recognized the merits of the rule, and official adoption of the rule would help the economic loss doctrine adhere to its true function in distinguishing between tort and warranty claims. ${ }^{235}$

\section{Factors to Help Analyze Tort Recovery in Home Construction Economic Loss Cases}

In addition to the independent duty rule, several factors may help in drawing distinctions between those home construction defects that should be actionable in tort and those that should be left to warranty law. None of these factors are determinative in themselves, but when taken together, they

230. David, 270 P.3d at 1109 (stating that the "independent duty analysis mirrors the rationale used by this court over several years to distinguish between causes of action arising in tort from those in contract in various types of litigation, including home construction").

231. Id. at 1115 .

232. Id. at 1109 .

233. Coker v. Siler, 304 P.3d 689, 696 (Kan. Ct. App. 2013).

234. Id. at 695-96 (remanding case for determination whether plaintiff's economic loss claim involved a duty independent of the underlying contract).

235. David, 270 P.3d at 1110 (quoting Koss Const. v. Caterpillar, Inc., 960 P.2d 255, 259 (Kan. Ct. App. 1998)) (stating that the purpose of the doctrine is to establish "a logical demarcation between cases properly pursued as tort actions and those which are warranty claims"). 
provide the basis for an accurate analysis of the claims. First, courts should consider the risk of harm presented by the defect. ${ }^{236}$ Courts should also consider the nature of the parties involved and their relative bargaining positions. ${ }^{237}$ The distinction between services contracts and products claims may provide another basis for analyzing home construction defects. Finally, whether a defect that causes economic loss also creates a risk of noneconomic harm can provide another basis for distinction in home construction cases.

First, and perhaps most importantly, the courts should look to the gravity of the harm that the defect creates. ${ }^{238}$ An analysis of the magnitude of harm could help prevent the potential for unlimited liability in these cases. There may simply be some harms in the home construction context that do not trigger the motivations of tort law in protecting parties outside the confines of the marketplace. ${ }^{239}$ A plaintiff who brings an action based on the negligent fitting of a door and discovers this six years after construction of the home is sufficiently protected by warranty law. On the other hand, a claimant who discovers that her home's foundation has been gradually cracking because of negligent pouring of concrete may require the protection of tort law. Distinguishing between those claims that are serious enough to require tort law protection and those that are not is difficult, and it does not provide a basis by itself for determining when the doctrine should apply. But by weighing the gravity of harm that a home defect causes, courts may be able to apply the doctrine in the construction context with less of a risk for unlimited liability.

Another factor that might help distinguish which home defects should be actionable is the type of parties involved. As the courts suggested, the

236. See Seely v. White Motor Co., 403 P.2d 145, 151 (Cal. 1965) ("A consumer should not be charged at the will of the manufacturer with bearing the risk of physical injury when he buys a product on the market."); Morris v. Osmose Wood Preserving, 667 A.2d 624, 631 (Md. 1995) (quoting Council of Co-Owners Atlantis Condo.Inc. v. Whiting-Turner, 517 A.2d 336, 345 (Md. 1986)) ("[T]he determination of whether a duty [in tort] will be imposed in [an economic loss case] should depend upon the risk generated by the negligent conduct, rather than upon the fortuitous circumstance of the nature of the resultant damage.").

237. See Van Lare v. Vogt, Inc., 683 N.W.2d 46, 54 (Wisc. 2004) (considering bargaining positions of parties in economic loss case).

238. See Pub. Bldg. Auth. of Huntsville v. St. Paul Fire \& Marine Ins. Co., 80 So. 3d 171, 186 (Ala. 2010) (stating as factors for tort liability consideration in economic loss cases "the moral blame attached to such conduct" and "the policy of preventing future harm").

239. See 14 CAL. JUR. 3D CONTRACTS $§ 2$ ("[T]ort law is designed to vindicate social policy.”); see also Jay M. Feinman, Implied Warranty, Products Liability, and the Boundary Between Contract and Tort, 75 WASH. U. L.Q. 469, 471 (1997) (describing tort law's concern "with 'social policy and risk allocation by means other than those dictated by the marketplace"" (quoting Denny v. Ford Motor Co., 662 N.E.2d 730, 736 (N.Y. 1995))). 
bargaining positions of the parties affect whether the economic loss doctrine should apply. ${ }^{240}$ One of the policies supporting the economic loss doctrine is the promotion of bargaining between parties. ${ }^{241}$ Courts have recognized that applying the doctrine in a business setting is beneficial because business parties generally share equivalent bargaining power. ${ }^{242}$ As noted above in Part III.B.2.a, a distinction based on bargaining power is more necessary in the residential construction context than in the business context. ${ }^{243}$ Similarly, in the construction context, a distinction based purely on whether the claimant is a consumer or business would not provide an adequate basis for determining whether to allow economic loss recovery. Businesses may have the same bargaining position as some homeowners, and, as in Rinehart, a party may fit into both categories. ${ }^{244}$ However, by considering this factor along with the true bargaining positions of the parties, courts can better determine which home construction claims should be actionable in tort.

The distinction between products and services could also serve as an effective basis for determining whether the doctrine should apply. This is particularly relevant in the construction context, where a claim may involve both a product and a service. Other jurisdictions have adopted the services exception as a way to determine which claims should be actionable in warranty law and which should be actionable in tort. ${ }^{245}$ Some jurisdictions, such as Wisconsin, apply the economic loss doctrine when a contract is predominantly for products rather than services. ${ }^{246}$ This rule might provide a good starting point in the construction context. As noted above, the Kansas courts took this factor into consideration in preventing application of

240. See David, 270 P.3d at 1114 (citations omitted) (stating that one of the reasons for preventing application of the doctrine is that "contracts governing residential construction rarely involve the sophisticated parties with equal bargaining positions present in commercial products cases").

241. Id. at 1113-14 (addressing the bargaining policy, as explained in East River).

242. E. River S.S. Corp. v. Transamerica Delaval, Inc., 476 U.S. 858, 873 (1986) ("Since a commercial situation generally does not involve large disparities in bargaining power... we see no reason to intrude into the parties' allocation of the risk.").

243. See supra Part II.A.2. for discussion on the potential for economic loss doctrine reform outside the residential construction context.

244. Rinehart v. Morton Bldgs., Inc., 305 P.3d 622, 625 (Kan. 2013) (explaining that the plaintiffs planned to use the structure as both their home residence and business location).

245. Springfield Hydroelectric Co. v. Copp, 779 A.2d 67, 72 (Vt. 2001) (noting the existence of the exception but finding that plaintiff did not meet the requirements of the exception).

246. 1325 N. Van Buren, LLC v. T-3 Grp., Ltd., 716 N.W.2d 822, 832 (Wis. 2006) (citing Linden v. Cascade Stone Co., Inc., 699 N.W.2d 189, 193 (Wisc. 2005)) ("[I]f the contract is a mixed contract for products and services, whether the economic loss doctrine applies depends upon whether the contract is predominantly for a product or for services."). 
the doctrine to home construction cases. ${ }^{247}$ But when a home construction contract is based predominantly on goods, warranty law adequately addresses the economic loss claims through Article 2 of the UCC. Therefore, a determination of whether a claim is based on services or products could help in establishing a clearer line for when the economic loss doctrine should apply.

It might also be helpful for courts to consider whether a condition that creates an economic loss also creates a risk of non-economic harm. In the home construction context, some defective conditions do not create the risk of physical injury while others do create such a risk. For example, a door negligently installed that simply lets in cold air likely creates only economic loss. A negligently constructed roof may cause only economic loss when the leak is not significant. By contrast, a negligently constructed foundation may create a risk of physical injury if the walls of the house are capable of caving in. The David opinion addressed this factor in passing by stating its concern with contractors escaping tort liability simply because a dangerous condition coincidently causes only economic harm rather than personal injury. ${ }^{248}$ Holding contractors liable for dangerous conditions when they cause economic harm may promote more careful construction and prevent injuries. If a condition has the potential for creating danger, a contractor would likely use greater care in its installation. The economic loss doctrine contemplates risk allocation for economic losses, but distinguishes this from personal injury claims, in which risk allocation is discouraged. ${ }^{249}$ When a risk of bodily harm arises but only economic losses ultimately result, it seems that tort law would have an interest in deterring the allocation of the risk of bodily harm between the parties. The economic loss doctrine could still apply to claims that do not create an unreasonable risk of bodily harm.

The Kansas courts seemed to emphasize these factors in their analysis of the economic loss claims in front of them. ${ }^{250}$ By incorporating these factors

247. As noted previously, warranty law seems to apply to service contracts with the duty to perform services in "a workmanlike manner," but Kansas courts may still have an interest in applying tort law to professional claims, which are not subject to this implied warranty. See supra note 153 .

248. David v. Hett, 270 P.3d 1102, 1114 (Kan. 2011).

249. See Grams v. Milk Prods., Inc., 699 N.W.2d 167, 173 (Wis. 2005) ("The economic loss doctrine, therefore, differentiates between economic losses, for which risk sharing is encouraged, and other losses, such as personal injury losses, where risk sharing is undesirable as a matter of public policy.”).

250. David, 270 P.3d at 1113-14 (discussing the relative bargaining experience of the parties, the nature of the alleged harm, and the suitability of the economic loss doctrine to services contracts); Rinehart v. Morton Bldgs., Inc., 305 P.3d 622, 632 (Kan. 2013) (discussing bargaining positions of parties). 
into economic loss analysis in other home construction cases, the courts could allow tort recovery when it is appropriate while properly limiting the sphere of liability. None of these factors provides a suitable basis for analysis in itself, but taken together they might help prevent the potential for unlimited liability when the economic loss doctrine is repealed in home construction cases.

\section{CONCLUSION}

The confusion surrounding the economic loss doctrine fuels innumerable applications of the doctrine throughout the United States. Some jurisdictions apply the economic loss doctrine in a wide range of contexts, effectively limiting plaintiffs to warranty claims when they seek economic loss damages. ${ }^{251}$ Others have chosen from a menu of exceptions to help reign in the scope of the doctrine. ${ }^{252}$ In Kansas, courts initially expanded the doctrine from products cases to construction and services claims.

However, David, Coker, and Rinehart explicitly limited the doctrine in at least some construction cases. Read broadly, these cases allow tort recovery for any economic loss claim in the home construction context when a plaintiff can find a legal duty outside the confines of the parties' contract. But this reading opens the door to tort liability in other economic loss contexts, blurs the line further between warranty and tort law, and creates the potential for unlimited liability in home construction cases. Therefore, courts must consider which home construction defects are worthy of additional protection outside of warranty law when the only harm caused is economic loss. By adopting the independent duty rule and applying several factors to economic loss doctrine analysis, the Kansas courts can prevent application of the doctrine in the most troubling home construction cases while also reasonably limiting the scope of tort liability in economic loss cases.

251. See generally AMERICAN BAR ASs'N, supra note 6 .

252. Id. 